CLINICAL STUDY

\title{
Serum TSH and serum thyroid peroxidase antibody fluctuate in parallel and high urinary iodine excretion predicts subsequent thyroid failure in a 1-year study of patients with untreated subclinical hypothyroidism
}

\author{
Jesper Karmisholt and Peter Laurberg \\ Department of Endocrinology and Medicine, Aalborg Hospital, Aarhus University Hospital, 9000 Aalborg, Denmark \\ (Correspondence should be addressed to J Karmisholt; Email: jsk@rn.dk)
}

\begin{abstract}
Objective: To explore the possibility of predicting decline or improvement in thyroid function over 1 year, and to investigate the correlations of serum TSH (s-TSH) with hypothyroidism-related symptoms and signs, serum thyroid peroxidase antibody (s-TPO-Ab) and urinary iodine excretion in individual patients with untreated subclinical hypothyroidism (SH).

Design: Monthly repeated measurement study without intervention.

Methods: Twenty-one patients without former thyroid disease who had been identified with s-TSH between 5 and $12 \mathrm{mU} / \mathrm{l}$ and normal serum thyroxine $\left(\mathrm{s}-\mathrm{T}_{4}\right)$ at two occasions were enrolled. Subsequently, 13 monthly measurements of s-TSH, hypothyroidism-related symptoms and signs, serum free $\mathrm{T}_{4}, \mathrm{~s}-\mathrm{TPO}-\mathrm{Ab}$ and urinary iodine excretion were performed.

Results: Over the study year, s-TSH increased significantly in 5 patients, 16 had unchanged s-TSH, whereas none improved. From clinical and biochemical inclusion data, it was not possible to predict who would later increase in s-TSH. In individual patients, a highly significant correlation between s-TSH and s-TPO-Ab was found $(r=0.37, P<0.0001)$ and also between s-TSH and urinary iodine excretion $(r=$ $0.14, P=0.034)$. No correlation between s-TSH and clinical symptoms and signs was observed. Time shift showed best correlation between s-TSH and s-TPO-Ab measured at the same time point, whereas urinary iodine excretion correlated best to s-TSH and s-TPO-Ab obtained 1 month later.

Conclusion: At the time of inclusion, it was not possible to identify the $24 \%$ of SH patients who would show deterioration in thyroid function over the following year. Impairment in thyroid function varied in parallel with thyroid autoimmunity, whereas high urinary iodine excretion predicted high s-TSH and s-TPO-Ab 1 month later.
\end{abstract}

European Journal of Endocrinology 158 209-215

\section{Introduction}

Subclinical hypothyroidism (SH) is a condition with serum thyrotrophin (TSH) above the upper reference limit for the assay and serum thyroxine $\left(\mathrm{T}_{4}\right)$ within the reference range. $\mathrm{SH}$ is frequent in most populations studied (1-5), but the underlying abnormalities responsible for development and variation in thyroid function in SH are poorly understood. SH is often linked to thyroid autoimmunity, and an association between elevated TSH and the presence of thyroid peroxidase antibody (TPO-Ab) in serum has been found in several cross-sectional studies (3, 4, 6-8). During long-term follow-up with large intervals between clinical controls, both high TSH and the presence of TPO-Ab are associated with a high risk of future progression to overt hypothyroidism (9) and some patients will normalise in thyroid function (10). Shortterm changes in TSH and TPO-Ab in serum in patients with $\mathrm{SH}$ on the other hand are largely unknown.
In intervention studies, it has been found that excessive iodine intake may worsen hypothyroidism in individuals with autoimmune thyroiditis $(11,12)$, and it may be speculated that variation in dietary iodine intake may influence thyroid function in patients with $\mathrm{SH}$.

We studied the course of thyroid function and hypothyroid symptoms and signs in patients with $\mathrm{SH}$, and how this was associated with variations in thyroid autoimmunity and iodine intake by monthly assessments during 1 year. We also investigated the possibility of predicting at the time of inclusion a decline or improvement in thyroid function over the subsequent year.

\section{Patients and methods}

After we had informed general practitioners in our area about the investigation, 44 patients with the result of a single TSH measurement in the interval 5-12 mU/l and a 
normal serum total $\mathrm{T}_{4}$ as controlled by their general practitioner were referred to us and contacted. After information about the study had been given, 34 patients were willing to participate and they were subsequently examined in our investigational unit. Thyroid function tests were performed 3 months after the initial test and patients still having TSH in the 5-12 mU/l interval and normal $\mathrm{T}_{4}$ were included in the study. Exclusion criteria were: former thyroid disease, age below 18 or above 80 years, change in any type of medication during the last 3 months, requirement of medication with influence on thyroid function, diseases with potential influence on thyroid function or pregnancy within the last 12 months. In 10 patients, thyroid function had normalised during the 'run-in' 3 months; thus, 21 participants, all Danish Caucasians were included during the period May 2004 to July 2005. The patients were recruited throughout the year and investigated according to inclusion date, in order to abolish any seasonal effect. All participants lived in or close to Aalborg, Jutland, Denmark, an area with previously moderately low iodine intake, but with effective salt iodisation since 2001 (13).

After inclusion, participants were investigated monthly on a total of 13 occasions. The interval between investigations was on average 37 days. The patients attended the investigational sessions after an overnight fast. One patient (patient 21) became progressively and overtly hypothyroid and, according to protocol, received $\mathrm{L}^{-} \mathrm{T}_{4}$ treatment after 4 months. This participant was excluded from the calculations as indicated.

Hypothyroid symptoms and signs were evaluated as described by Zulewski (14). This clinical evaluation included seven thyroid-related symptoms and five signs that are summarised in a total score. Higher score indicates more thyroid-related symptoms and signs. Patients were weighed (digital weight, SECA, Kolding, Denmark) in light clothing and height measured with a stadiometer. Thyroid volume was estimated ultrasonographically, by the use of a Siemens Sonoline Versa Pro (Siemens, Munich, Germany) and a $70 \mathrm{~mm} 7.5 \mathrm{MHz}$ linear transducer as described in detail by Knudsen et al. (15). All ultrasound measurements were performed using the same experienced operator. Blood samples were drawn between 0900 and $1200 \mathrm{~h}$ after the patients had been in supine position for $30 \mathrm{~min}$ and after brief venous occlusion. Samples were centrifuged at $1200 \mathrm{~g}$ and frozen at $-20{ }^{\circ} \mathrm{C}$ shortly after the investigational session. Urine samples were fasting spot urine.

\section{Assays}

All assays performed on the study samples were done as single batch operations of samples in random order using an Electro-Chemi Luminescence ImmunoAssay method on a Modular Analytics E170 (Roche). Assay characteristics given by the manufacturer with detection limits and normal ranges were as follows: TSH, $0.005 \mathrm{mU} / \mathrm{l}$, $0.27-4.2 \mathrm{mU} / \mathrm{l}$ and $\mathrm{fT}_{4}, 0.3 \mathrm{pmol} / \mathrm{l}, 12-22 \mathrm{pmol} / \mathrm{l}$. Intra-assay coefficient of variation (CV) for the TSH and
$\mathrm{fT}_{4}$ assays were 4.5 and $3.4 \%$. Total $\mathrm{T}_{4}$ for the inclusion was measured on the same apparatus, with lower detection limit of $5.4 \mathrm{nmol} / \mathrm{l}$, laboratory reference range of $60-140 \mathrm{nmol} / \mathrm{l}$ and total precision $\mathrm{CV}$ of $3.7 \%$. TPO-Ab and thyroglobulin antibody (Tg-Ab) were measured by anti-TPOn and anti-Tgn KRYPTOR (BRAHMS, Henningsdorf, Germany). Analytical sensitivity for TPO-Ab was $10 \mathrm{U} / \mathrm{ml}$, intra-assay $\mathrm{CV} \%$ 4.2 and inter-assay CV\% 9.7. Analytical sensitivity for $\mathrm{Tg}-\mathrm{Ab}$ was $10 \mathrm{U} / \mathrm{ml}$, intra-assay $\mathrm{CV} \%$ (for the range 55.4-502 U/ml) 4.7 and inter-assay CV\% (for the range $69.3-517 \mathrm{U} / \mathrm{ml}) 6.5$, as stated by the manufacturer. Urinary iodine was determined by the Ceri/Arsenium method after alkaline ashing $(16,17)$ and expressed as estimated 24-h urinary iodine excretion ( $\mu \mathrm{g} ; 24-\mathrm{h}$ U-iodine excretion), estimated from concentrations of iodine and creatinine in the spot urine samples as described by Knudsen et al. (18). For the estimations, sexand age-specific 24-h urinary creatinine excretions as provided by Kesteloots et al. (19) were used. Urinary creatinine was measured by a kinetic Jaffé method. All investigational sessions except one were performed using the same investigator ( J K).

All participants signed an informed consent form before entering the study, and the study was approved by the Regional Ethics Committee in North-Jutland and Viborg County, Denmark.

\section{Statistical evaluation}

Linear regression was used for estimation of trends over time. Differences in trends between two groups were investigated with the use of summary measure as described by Matthew \& Altman (20). Individual regression coefficients of variables versus time were used as summary measures. For comparison between groups, Mann-Whitney and Fisher's exact tests were used as appropriate. Within-person correlation and betweenperson correlation were calculated as suggested by Bland \& Altman (21). Pearson correlation coefficient was used for time-shifted correlation analyses. Differences were considered significant at $P<0.05$. Statistical Package for Social Sciences (SPSS versus 11.0, Chicago, IL, USA) and Excel 2003 (Microsoft Corp.) were used for statistical calculations.

\section{Results}

Patients' characteristics at first investigation after inclusion are shown in Table 1. TSH, $\mathrm{fT}_{4}$ and TPO-Ab displayed significant trends, over the next 12 months when analysed for the entire group of patients. TSH increased linearly with time $(P=0.002)$, whereas $\mathrm{fT}_{4}$ decreased $(P=0.002)$ and TPO-Ab increased linearly $(P=0.002)$. Hypothyroid symptom score showed no time dependency $(P=0.90)$, neither did 24-h U-iodine excretion $(P=0.96)$. On the basis of linear models, time to reach a $10 \%$ difference from 
Table 1 Patient characteristics at the first investigation after inclusion.

\begin{tabular}{|c|c|c|c|c|}
\hline & All patients & Positive trend in TSH & No trend in TSH & $P$ value* \\
\hline No. of patients ${ }^{a}$ & 21 & 5 & 16 & \\
\hline Sex (male/female) ${ }^{a}$ & $2 / 19$ & $0 / 5$ & $2 / 14$ & 1.00 \\
\hline Tobacco (yes/no) ${ }^{a}$ & $4 / 17$ & $0 / 5$ & $4 / 12$ & 0.53 \\
\hline BMI $\left(\mathrm{kg} / \mathrm{m}^{2}\right)$ & $26.5(25-33)$ & $25.7(24-26)$ & $27.4(25-35)$ & 0.10 \\
\hline Age (years) & $57(51-66)$ & $55(34-62)$ & $57(52-67)$ & 0.25 \\
\hline $\mathrm{TS} \mathrm{H}(\mathrm{mU} / \mathrm{l})$ & $6.5(4.9-8.0)$ & $7.8(4.7-8.6)$ & $6.2(5.0-8.0)$ & 0.62 \\
\hline $\mathrm{fT}_{4}(\mathrm{pmol} / \mathrm{l})$ & $13.7(12.6-14.5)$ & $13.5(12.6-14.1)$ & $14.2(12.6-14.6)$ & 0.48 \\
\hline TPO-Ab $\left(10^{3} \times \mathrm{kU} / \mathrm{l}\right)$ & $1.75(0.76-10.5)$ & $1.00(0.31-14.0)$ & $4.90(9.10-11.1)$ & 0.46 \\
\hline $\operatorname{Tg}-\mathrm{Ab}(\mathrm{kU} / \mathrm{l})$ & $115(7.5-280)$ & $115(7.5-362)$ & $129(16-266)$ & 0.87 \\
\hline 24-h U-iodine $(\mu \mathrm{g})$ & $102(82-147)$ & $102(67-134)$ & $105(83-153)$ & 0.41 \\
\hline Thyroid volume (ml) & $9.5(7.0-11.2)$ & $7.6(5.7-9.9)$ & $9.7(7.4-12.8)$ & 0.08 \\
\hline Hypothyroid score & $2(1-3)$ & $1(0-1)$ & $2(1.25-3)$ & 0.97 \\
\hline
\end{tabular}

Data are shown for all patients with subclinical hypothyroidism and for groups according to trend in s-TSH over the following 1 year. BMI, body mass index; $\mathrm{TSH}$, thyroid stimulating hormone; $\mathrm{fT}_{4}$, free thyroxine; TPO-Ab, thyroid peroxidase antibody; Tg-Ab, thyroglobulin antibody; U-iodine, urinary iodine ${ }^{*} P$ value for comparison of groups with and without trend in TSH using Fisher's exact or Mann-Whitney tests as appropriate.

anumbers; all other values are medians (interquartile range).

baseline was 7.8 months for TSH and 15.7 months for $\mathrm{fT}_{4}$. Time for TPO-Ab to reach a $10 \%$ difference was 6.6 months, comparable with that for TSH.

\section{Subgroups of patients with different course in TSH}

In the individual patient, TSH might theoretically decrease, increase or remain unchanged with time. When trend in TSH over time for each patient was estimated by linear regression, none of the patients had a significant decrease in TSH. Five patients (patient number $10,13,17,19$ and 21) had a significant increase and 16 patients had no statistical significant change in TSH during the study period. Figure 1 displays the average $\mathrm{TSH}, \mathrm{fT}_{4}$, hypothyroid score and 24-h U-iodine excretion over 1 year in patients stratified according to trend in TSH. The group of patients with an increase in TSH had a more pronounced decrease in $\mathrm{fT}_{4}(-0.19 \mathrm{pmol} / \mathrm{l}$ per month versus $-0.06 \mathrm{pmol} / \mathrm{l}$ per month, $P=0.03)$, and increase in hypothyroid score $(0.14$ score/month versus -0.018 score/month, $P=0.014$ ) and 24-h U-iodine excretion $(5.3 \mu \mathrm{g} / 24 \mathrm{~h}$ per month versus $-2.5 \mu \mathrm{g} / 24 \mathrm{~h}$ per month, $P=0.011)$ compared with the group with no change in TSH. On the other hand, we observed no differences with regards to changes in TPO-Ab $(2.7 \mathrm{kU} / \mathrm{l}$ per month versus $4.6 \mathrm{kU} / \mathrm{l}$ per month, $P=0.113)$ and $\mathrm{Tg}-\mathrm{Ab}(262.1 \mathrm{kU} / \mathrm{l}$ per month versus $76.2 \mathrm{kU} / \mathrm{l}$ per month, $P=0.186$ ) between the two trend groups.

The possibility of forecasting at the time of inclusion which patient would have an increase in TSH during the subsequent 12 months of follow-up was investigated as shown in Table 1. No significant differences were observed between the two groups of patients at the time of inclusion.

\section{Association between thyroid insufficiency and antibody level in the individual patient}

The associations between TSH and hypothyroid score, $\mathrm{fT}_{4}$, TPO-Ab, Tg-Ab or 24-h U-iodine excretion in the individual patient were evaluated by within-person correlation analyses as shown in Table 2. As expected strong correlations were observed between $\mathrm{TSH}$ and $\mathrm{fT}_{4}$, but also between TSH and TPO-Ab, whereas a weaker correlation was found between TSH and 24-h U-iodine excretion. Hypothyroid score and Tg-Ab did not correlate to TSH (Table 2). The parallel fluctuations between TSH and $\mathrm{TPO}-\mathrm{Ab}$ in the individual patients are illustrated in Fig. 2.

\section{Time sequence of changes in TSH, TPO-Ab and 24-h $U$-iodine excretion}

We studied if correlations between some variables were dependent on whether the variables were in phase or not. This was done by calculating coefficients of correlations with time shifts between the variables. Figure 3 shows mean of individual Pearson correlation coefficients with no time shifts between variables (abscissa value 0 , indicated by vertical dotted line) and when variables were up to 6 months out of phase. As seen in the upper panel of Fig. 3, a positive correlation between TPO-Ab and TSH was seen over a broad time interval from TPO-Ab measured 2 months before to 1 month after TSH, whereas the only substantial correlation between 24-h U-iodine excretion and TSH was obtained using the 24-h U-iodine excretion value taken 1 month before the TSH value (middle panel). Similarly, Fig. 3, lower panel, shows that 24-h U-iodine excretion obtained 1 month before the TPO-Ab value gave the highest, and positive, mean correlation value.

\section{Discussion}

In this cohort of patients with untreated SH followed closely for 1 year, none improved in thyroid function whereas $24 \%$ showed deterioration, with a significant increase in TSH. Several investigations have carried out follow-up studies on patients with $\mathrm{SH}(10,22-26)$, but none of these studies used as short and regular control intervals as the present study. 

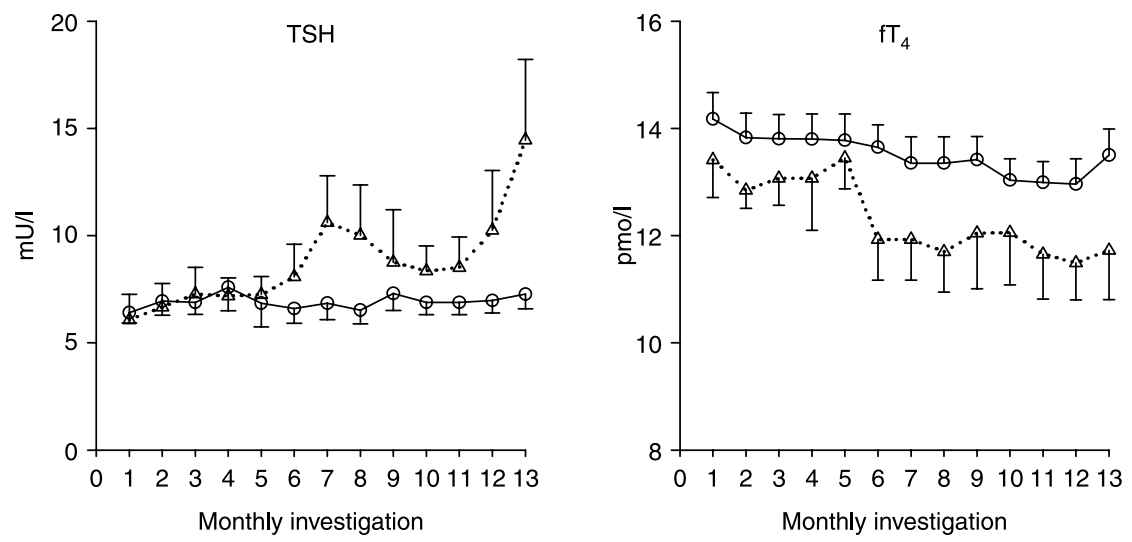

\section{$\underline{\mathrm{O}}-\mathrm{TSH}$ trend $\ldots . . . .+\mathrm{TSH}$ trend}
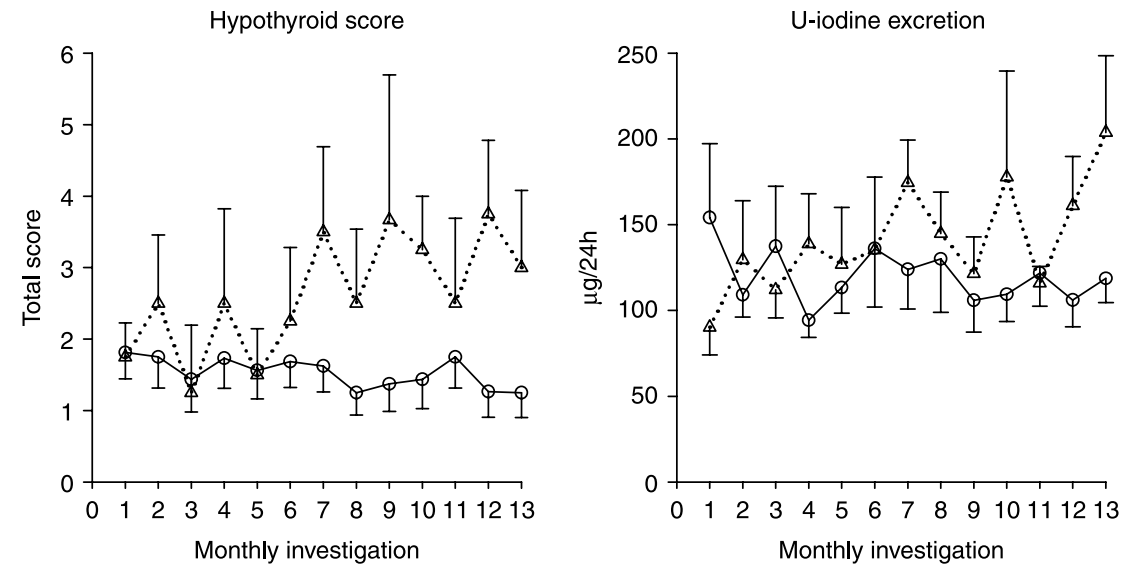

Figure 1 Serum $\mathrm{TSH} \mathrm{fT}_{4}$, hypothyroid score and 24-h urinary iodine excretion measured 13 times over 1 year in patients with increasing TSH (+TSH trend, $n=4$, dotted line with triangles) and in patients without stable TSH values ( $-\mathrm{TSH}$ trend, $n=16$, solid line with circles). Values are mean ( \pm S.E.M.). The patient who developed profound overt hypothyroidism and started therapy was excluded from calculations. $P$ values of differences between the groups were: $\mathrm{fT}_{4}, P=0.03$; hypothyroid score, $P=0.01$ and urinary iodine excretion, $P=0.01$.

Four-year follow-up of SH patients from the Wickham study showed that 8 out of 48 developed $\mathrm{OH}$. Seven out of these eight patients had both microsomal antibodies and elevated TSH at the first investigation, but levels were not different in the individuals who developed $\mathrm{OH}$ compared with the rest of the cohort with SH (23). Dies \& Iglesias (26) followed 107 $\mathrm{SH}$ patients for a mean of 32 months. Twenty-eight required $\mathrm{L}_{-} \mathrm{T}_{4}$ treatment during follow-up and 40 normalised thyroid function. Initial TSH level was predictive of future decline in thyroid function in this cohort. One (5\%) of the patients in the present study developed requirement of $\mathrm{L}-\mathrm{T}_{4}$ treatment and $24 \%$ shared a decline in thyroid function over the relatively short time span of 12 months. At the time of inclusion, it was not possible to predict which patients would have a further decrease in thyroid function.

The association between TSH and TPO-Ab has been studied in a number of cross-sectional studies (3, 4, 6-8). In the DanThyr cohort studied by Pedersen et al. (6), high TPO-Ab was found to associate with high TSH. The association was present at TSH above $2.5 \mathrm{mU} / \mathrm{l}$. In patients with untreated SH, within-person correlation between TSH and TPO-Ab has not previously been evaluated. When our patients were observed as a cohort, a positive but insignificant correlation $(r=0.40, P=0.08)$ was found between TSH and TPO-Ab. On the other hand, when individual patients were studied over 1 year a highly

Table 2 Within-person correlations between serum thyrotrophin (s-TSH) and free thyroxine ( $\mathrm{fT}_{4}$ ), hypothyroid score, thyroid peroxidase antibody (TPO-Ab), thyroglobulin antibody ( $\mathrm{Tg}-\mathrm{Ab}$ ) and 24-h urinary iodine excretion (U-iodine).

\begin{tabular}{lcc}
\hline Serum TSH versus & Correlation coefficient $\boldsymbol{r}^{\mathrm{a}}$ & $\boldsymbol{P}$ value \\
\hline $\mathrm{fT}_{4}$ & -0.43 & $<0.001$ \\
$\mathrm{TPO}-\mathrm{Ab}$ & 0.37 & $<0.001$ \\
$\mathrm{Tg}$-Ab & 0.09 & 0.15 \\
U-iodine & 0.14 & 0.034 \\
Hypothyroid score & -0.017 & 0.79
\end{tabular}

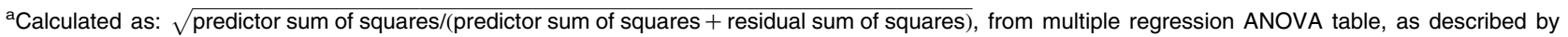
Bland \& Altman (21). $\mathrm{fT}_{4}$, free thyroxine; TPO-Ab, thyroid peroxidase antibody; Tg-Ab, thyroglobulin antibody; U-iodine, urinary iodine. 

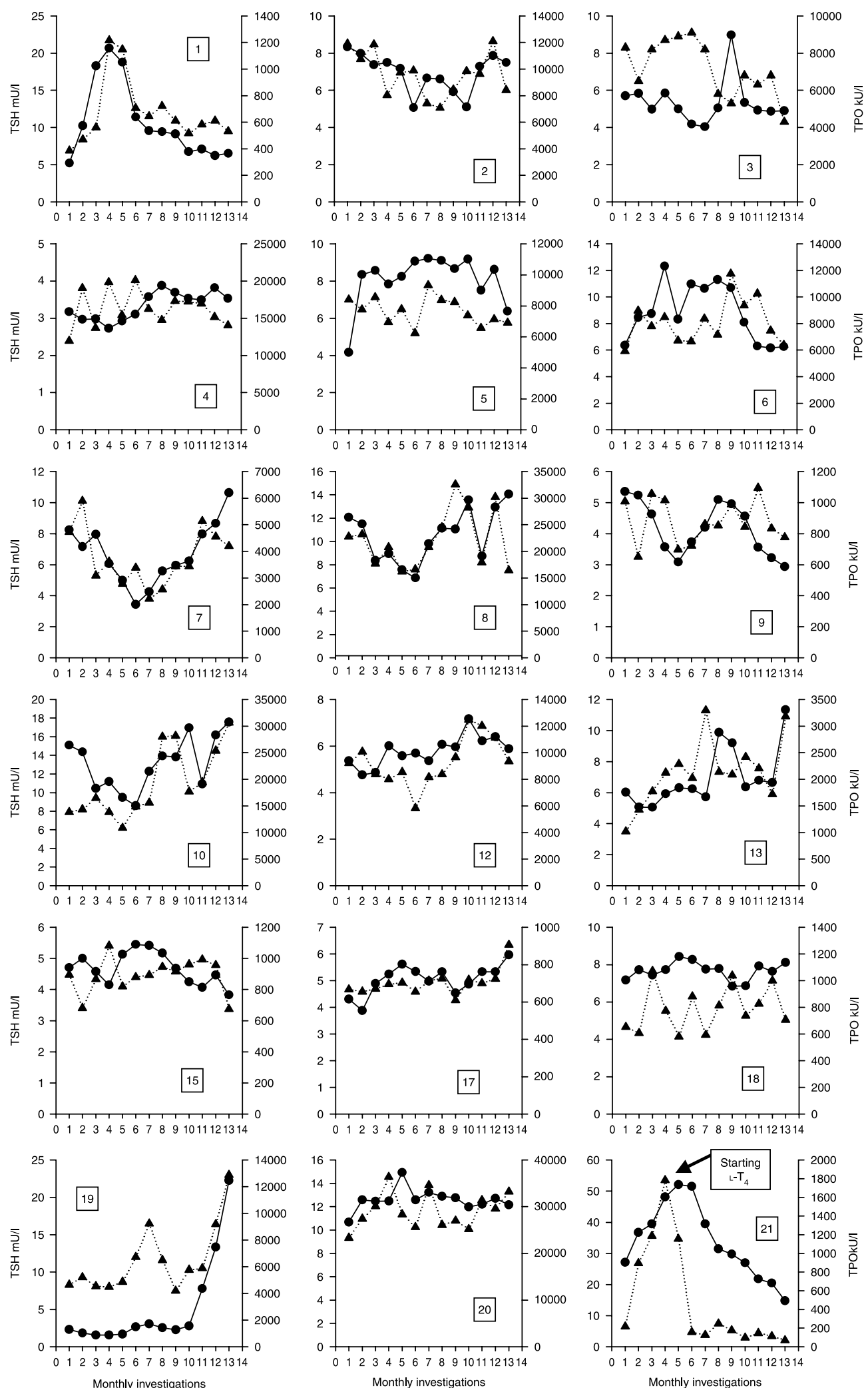

Figure 2 Thirteen monthly s-TSH values (dotted lines, triangles) and Serum thyroid peroxidase antibody (s-TPO-Ab) values (solid lines, circles) for the 18 patients with measurable TPO-Ab (the number in the box corresponds to patient number). Patient 21 was started on L-T 4 treatment after the fourth investigation. 

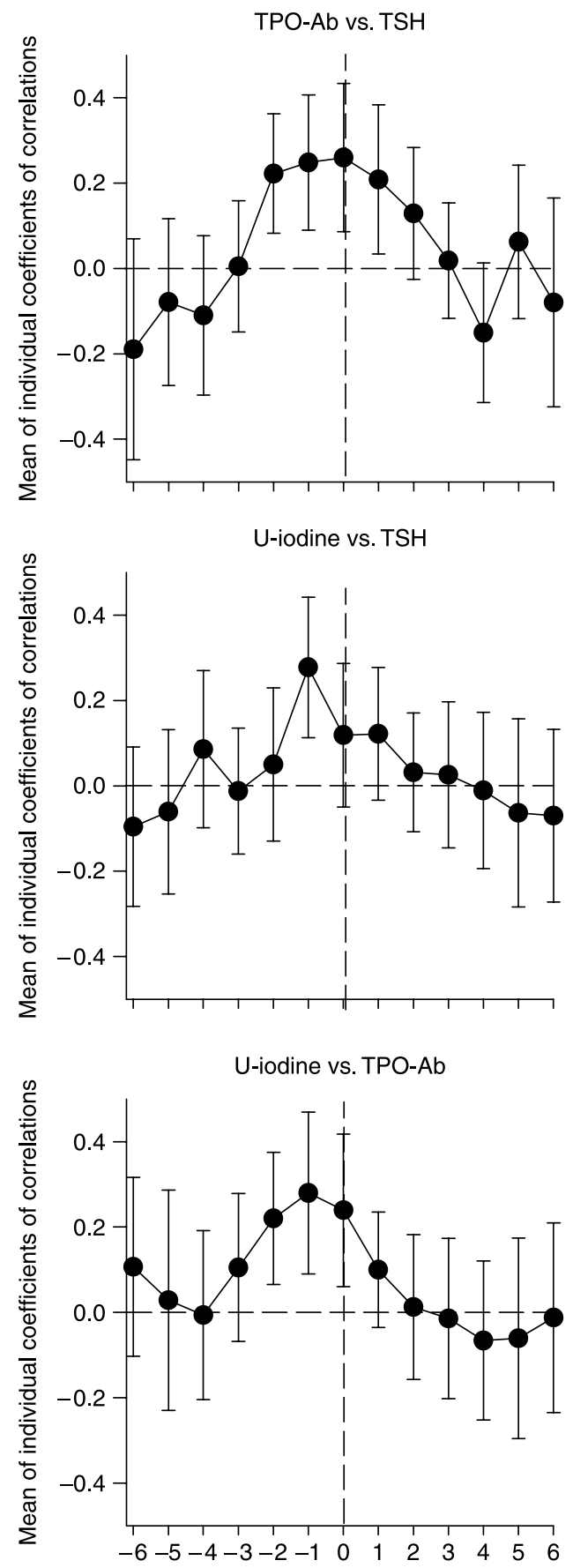

Difference in time (months) between the first and second variable

Figure 3 Mean ( \pm 2 s.E.M.) of individual Pearson correlation coefficients between the variables indicated. Coefficients were calculated with no time shifts between variables (abscissa value 0 , indicated by vertical dotted line) and when variables were up to 6 months out of phase. Markers to the left of the vertical dotted line represent correlations between the variables when the first variables were taken 1-6 months before the second. The right side of the vertical dottedline is the correlation when the first variables were taken 1-6 months after. Error bars not crossing the horizontal zero line indicate that the mean values are significantly different from $0(P<0.05)$. significant positive within-person correlation between TSH and TPO-Ab was observed. Thus, in the individual patient, variation in thyroid failure paralleled activity in thyroid autoimmunity.

High iodine intake may lead to thyroid failure (5). Whether the major mechanism is iodine triggering of thyroid autoimmunity or whether it is a direct inhibitory effect on thyroid hormone production and secretion has been discussed for several years. Bournaud \& Orgiazzi (27) reviewed the topic, and concluded that from a populationbased perspective iodine sufficiency favours occurrence of autoimmune thyroid disease, but the effect of iodine administration appears to depend on several factors, such as iodine status of the recipient, dose of administered iodine, degree of stimulation of the thyroid gland and genetic factors. Reinhardt et al. (11) gave, in a randomised controlled study, a small amount of iodine to individuals with euthyroid Hashimoto's thyroiditis. The study subjects lived in a mildly iodine-deficient area. Seven persons in the treatment group $(n=40)$ and one in the control group $(n=43)$ developed SH. No change in TPO-Ab levels were observed, suggesting a direct inhibitory effect of iodine on thyroid hormone production/secretion. In our study, correlations between TSH and TPO-Ab or 24-h U-iodine excretion indicated that timing of events was important. The positive correlation between TSH and TPO-Ab took place over several months. On the other hand, 24-h U-iodine excretion correlated best to TSH values obtained 1 month later and also to TPO-Ab values obtained 1 month after 24-h U-iodine excretion. Our findings may indicate an additive effect of minor dietary increases in iodine intake and a surge in thyroid autoimmunity on thyroid failure in patients with $\mathrm{SH}$.

\section{Limitations}

The patients studied by us were included after SH had been confirmed on two occasions 3 months apart, whereas many other studies have included patients with only one set of abnormal thyroid function tests $(10,22,23,25)$. This is probably the reason that none of our patients improved in thyroid function over the subsequent year, whereas this has been frequent in other studies $(10,22,23)$. The urinary iodine excretion of the patients in the present study was still borderline low despite the Danish salt iodisation programme that has been effective since 2001 (13). Fasting spot urine samples, as were used in the present study, are known to have lower iodine content than non-fasting spot samples (28). Fasting urinary iodine concentration may represent a broader measure of the iodine status over a period than non-fasting concentrations, as the iodine concentration in a non-fasting urine sample to a high degree reflects the iodine content of the preceding meal.

\section{Conclusion}

In the individual patient, it was not possible to predict at the time of inclusion, whether there would be progression 
in thyroid failure over the coming year. When studied closely, considerable fluctuations were found in thyroid function in patients with SH. In the individual patients, thyroid failure correlated closely to thyroid autoimmune activity but also to iodine intake during the preceding period. Iodine intake and thyroid autoimmunity may act synergistically to determine short-term variation in thyroid function in patients with SH.

\section{Acknowledgements}

We are indebted to laboratory technicians Ingelise Leegaard and Anne-Mette Christensen for invaluable assistance with thyroid ultrasound investigations and biochemical analyses.

\section{References}

1 Tunbridge WM, Evered DC, Hall R, Appleton D, Brewis M, Clark F, Evans JG, Young E, Bird T \& Smith PA. The spectrum of thyroid disease in a community: the Whickham survey. Clinical Endocrinology 1977 781-493.

2 Knudsen N, Bulow I, Jorgensen T, Laurberg P, Ovesen L \& Perrild H. Comparative study of thyroid function and types of thyroid dysfunction in two areas in Denmark with slightly different iodine status. European Journal of Endocrinology 2000143 485-491.

3 Bjoro T, Holmen J, Kruger O, Midthjell K, Hunstad K, Schreiner T, Sandnes L \& Brochmann H. Prevalence of thyroid disease, thyroid dysfunction and thyroid peroxidase antibodies in a large, unselected population. The Health Study of Nord-Trondelag (HUNT). European Journal of Endocrinology 2000143 639-647.

4 Hollowell JG, Staehling NW, Flanders WD, Hannon WH, Gunter EW, Spencer CA \& Braverman LE. Serum TSH, T(4), and thyroid antibodies in the United States population (1988 to 1994): National Health and Nutrition Examination Survey (NHANES III). Journal of Clinical Endocrinology and Metabolism 2002 87 489-499.

5 Teng W, Shan Z, Teng X, Guan H, Li Y, Teng D, Jin Y, Yu X, Fan C, Chong W, Yang F, Dai H, Yu Y, Li J, Chen Y, Zhao D, Shi X, Hu F, Mao J, Gu X, Yang R, Tong Y, Wang W, Gao T \& Li C. Effect of iodine intake on thyroid diseases in China. New England Journal of Medicine 2006354 2783-2793.

6 Bulow Pedersen I, Laurberg P, Knudsen N, Jorgensen T, Perrild H, Ovesen L \& Rasmussen LB. A population study of the association between thyroid autoantibodies in serum and abnormalities in thyroid function and structure. Clinical Endocrinology 200562 713-720.

7 Hoogendoorn EH, Hermus AR, de Vegt F, Ross HA, Verbeek AL, Kiemeney LA, Swinkels DW, Sweep FC \& den Heijer M. Thyroid function and prevalence of anti-thyroperoxidase antibodies in a population with borderline sufficient iodine intake: influences of age and sex. Clinical Chemistry 200652 104-111.

8 O'Leary PC, Feddema PH, Michelangeli VP, Leedman PJ, Chew GT, Knuiman M, Kaye J \& Walsh JP. Investigations of thyroid hormones and antibodies based on a community health survey: the Busselton thyroid study. Clinical Endocrinology 2006 64 97-104.

9 Vanderpump MP, Tunbridge WM, French JM, Appleton D, Bates D, Clark F, Grimley EJ, Hasan DM, Rodgers H \& Tunbridge F. The incidence of thyroid disorders in the community: a twenty-year followup of the Whickham Survey. Clinical Endocrinology 199543 55-68.

10 Parle JV, Franklyn JA, Cross KW, Jones SC \& Sheppard MC. Prevalence and follow-up of abnormal thyrotrophin (TSH) concentrations in the elderly in the United Kingdom. Clinical Endocrinology 199134 77-83.
11 Reinhardt W, Luster M, Rudorff KH, Heckmann C, Petrasch S, Lederbogen S, Haase R, Saller B, Reiners C \& Mann K. Effect of small doses of iodine on thyroid function in patients with Hashimoto's thyroiditis residing in an area of mild iodine deficiency. European Journal of Endocrinology 1998139 23-28.

12 Chow CC, Phillips DI, Lazarus JH \& Parkes AB. Effect of low dose iodide supplementation on thyroid function in potentially susceptible subjects: are dietary iodide levels in Britain acceptable? Clinical Endocrinology 199134 413-416.

13 Laurberg P, Jorgensen T, Perrild H, Ovesen L, Knudsen N, Pedersen IB, Rasmussen LB, Carle A \& Vejbjerg P. The Danish investigation on iodine intake and thyroid disease, DanThyr: status and perspectives. European Journal of Endocrinology 2006155 219-228.

14 Zulewski H, Muller B, Exer P, Miserez AR \& Staub JJ. Estimation of tissue hypothyroidism by a new clinical score: evaluation of patients with various grades of hypothyroidism and controls. Journal of Clinical Endocrinology and Metabolism 199782 771-776.

15 Knudsen N, Bulow I, Jorgensen T, Laurberg P, Ovesen L \& Perrild H. Goitre prevalence and thyroid abnormalities at ultrasonography: a comparative epidemiological study in two regions with slightly different iodine status. Clinical Endocrinology 200053 479-485.

16 Wilson B \& Van Zyl A. The estimation of iodine in thyroidal amino acids by alkaline ashing. The South African Journal of Medical Sciences 196732 70-82.

17 Laurberg P. Thyroxine and 3,5,3'-triiodothyronine content of thyroglobulin in thyroid needle aspirates in hyperthyroidism and hypothyroidism. Journal of Clinical Endocrinology and Metabolism 198764 969-974.

18 Knudsen N, Jorgensen T, Rasmussen S, Christiansen E \& Perrild H. The prevalence of thyroid dysfunction in a population with borderline iodine deficiency. Clinical Endocrinology 199951 361-367.

19 Kesteloot H \& Joossens JV. On the determinants of the creatinine clearance: a population study. Journal of Human Hypertension 1996 10 245-249.

20 Matthews JN, Altman DG, Campbell MJ \& Royston P. Analysis of serial measurements in medical research. BMJ 1990300 230-235.

21 Bland JM \& Altman DG. Calculating correlation coefficients with repeated observations: Part 1 - correlation within subjects. British Medical Journal $1995 \mathbf{3 1 0} 446$.

22 Nystrom E, Bengtsson C, Lindquist O, Noppa H, Lindstedt G \& Lundberg PA. Thyroid disease and high concentration of serum thyrotrophin in a population sample of women. A 4-year followup. Acta Medica Scandinavica 1981210 39-46.

23 Tunbridge WM, Brewis M, French JM, Appleton D, Bird T, Clark F, Evered DC, Evans JG, Hall R, Smith P, Stephenson J \& Young E. Natural history of autoimmune thyroiditis. British Medical Journal $1981282258-262$.

24 Kabadi UM. 'Subclinical hypothyroidism'. Natural course of the syndrome during a prolonged follow-up study. Archives of Internal Medicine 1993153 957-961.

25 Huber G, Staub JJ, Meier C, Mitrache C, Guglielmetti M, Huber P \& Braverman LE. Prospective study of the spontaneous course of subclinical hypothyroidism: prognostic value of thyrotropin, thyroid reserve, and thyroid antibodies. Journal of Clinical Endocrinology and Metabolism 200287 3221-3226.

26 Diez JJ \& Iglesias P. Spontaneous subclinical hypothyroidism in patients older than 55 years: an analysis of natural course and risk factors for the development of overt thyroid failure. Journal of Clinical Endocrinology and Metabolism 200489 4890-4897.

27 Bournaud C \& Orgiazzi JJ. Iodine excess and thyroid autoimmunity. Journal of Endocrinological Investigation 200326 49-56.

28 Rasmussen LB, Ovesen L \& Christiansen E. Day-to-day and withinday variation in urinary iodine excretion. European Journal of Clinical Nutrition 199953 401-407.

Received 24 October 2007

Accepted 26 October 2007 